Rule 13: In the rules which the apostles gave to their churches in things indifferent, the Church hath a liberty; but it is not to be used but for great reason and great necessity, and for the edification of the people committed to their charge.

Rule 14: The canons of the ancient general and provincial councils are then laws to the conscience when they are bound upon us by the authority of the respective governors of churches.

Rule 15: The laudable customs of the Catholic Church which are in present observation do oblige the conscience of all Christians.

Rule 16: The decrees and canons of the bishops of Rome oblige the conscience of none but his own subjects.

Rule 17: Ecclesiastical laws that are merely such cannot be universal and perpetual.

Rule 18: Ecclesiastical laws and circumstances of external observances do not bind the conscience beyond the cases of contempt and scandal.

Rule 19: Ecclesiastical laws must be charitable and easy, and when they are not, they oblige not.

Rule 20: Ecclesiastical laws must ever promote the service of God and the good of souls; but must never put a snare or stumbling block to consciences.

\title{
1994 ANNUAL CONFERENCE
}

\author{
SATURDAY 26 MARCH
}

CHURCH HOUSE WESTMINSTER

(Harvey Goodwin Suite)

GUEST SPEAKER

THE RT. HON. THE LORD MACKAY OF CLASHFERN LORD HIGH CHANCELLOR

Plus A PANEL TO RECEIVE QUESTIONS ON

Blasphemy - Cost of Discipline - Can there be two integrities?

Probable Cost (including refreshments \& lunch) c. $£ 22$

Details (0664-840262)

Booking Form to follow 